\title{
Extra-anatomic microvascular second toe transfer for creation of a helper hand - a long-term follow-up
}

\author{
L Shayne Webb MD, James L Dolph MD
}

\begin{abstract}
LS Webb, JL Dolph. Extra-anatomic microvascular second toe transfer for creation of a helper hand - a long-term follow-up. Can J Plast Surg 2008;16(2):92-94.
\end{abstract}

\begin{abstract}
Mutilating hand injuries can significantly alter a patient's life. Return to work and daily activities remain the ultimate goal. A case report and long-term follow-up of a patient who caught his hand in a generator fan at work is presented. He sustained an injury that left him with a wrist and metacarpal stump. When prostheses failed, an extraanatomic second toe transfer was used to produce a functional distal extremity. This transfer allowed the patient to return to his job and was surprisingly durable, resulting in a useful helper hand for 15 years.
\end{abstract}

Key Words: Helper hand; Metacarpal stump; Second toe transfer

\section{Greffe microvasculaire extra-anatomique du deuxième orteil pour la création d'une main auxiliaire : Suivi à long terme}

\begin{abstract}
Les mutilations de la main peuvent bouleverser considérablement la vie des patients. Le retour au travail et la reprise des activités normales restent les objectifs ultimes. On présente ici un rapport de cas et de suivi à long terme d'un patient qui s'est coincé la main dans un ventilateur de génératrice. Il a subi un traumatisme qui ne lui a laissé que le poignet et un moignon métacarpien. Après l'échec des prothèses, une greffe extraanatomique du second orteil a été utilisée pour reconstruire un membre distal fonctionnel. Cette transplantation a permis au patient de retourner au travail et la greffe a tenu étonnamment longtemps. Il a ainsi bénéficié d'une main auxiliaire utile pendant une durée de 15 ans.
\end{abstract}

$\mathrm{N}$ onanatomic toe transfer has been previously discussed for hand reconstruction $(1,2)$. Devastating hand loss can sometimes be successfully treated with hand prostheses $(3,4)$; however, some patients cannot or will not use or tolerate such appliances. In these patients, extra-anatomic toe transfer can produce a functional distal extremity and allow the patient to return to work. We present a case and 15-year follow-up of an extra-anatomic microvascular second toe transfer for creation of a helper hand.

\section{CASE PRESENTATION}

In January 1991, a 42-year-old right-handed man caught his left hand in a generator fan at work. He was noted to have a devastating crush/degloving injury to the left hand. Multiple small parts were brought in but were not replantable. The soft tissue injury started at the level of the wrist crease and extended distally. Denuded carpals and metacarpals were left. Debridement of devitalized tissues and split-thickness skin graft coverage resulted in a wrist and metacarpal stump (Figure 1). A prosthesis was tried, but the patient did not tolerate the appliance. The patient was deemed an appropriate candidate for extra-anatomic free second toe transfer for creation of a helper hand. Come along grasp would be via the wrist and metacarpal stumps; pinch grasp would be via the nonanatomic free second toe transfer to distal radius.

In September 1992, the patient was brought to the operating room. Using a standard two team approach, simultaneous dissection of the left arm and left foot was performed.

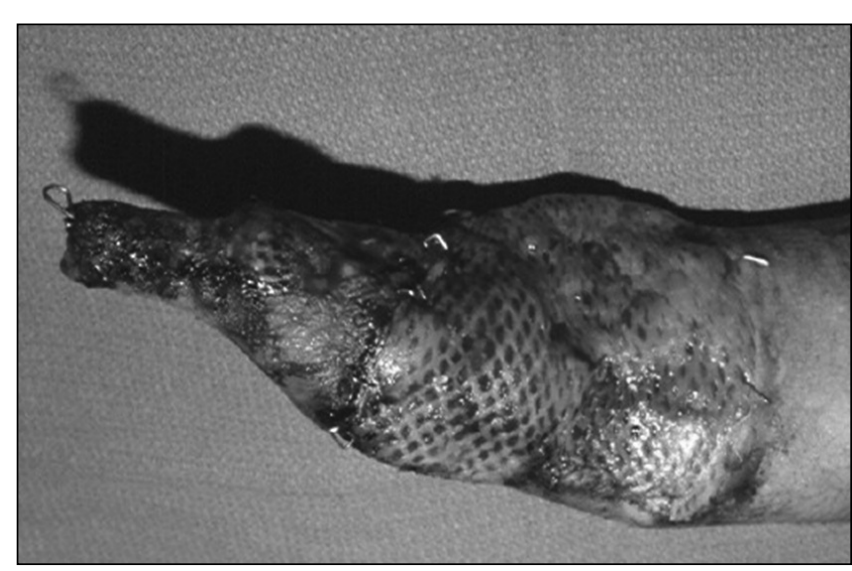

Figure 1) Wrist and metacarpal stump

\section{Arm dissection}

Under tourniquet, the arm was entered through a curvilinear incision made over the volar and radial surface of the distal left arm. The radial artery and cephalic vein were isolated to provide for inflow and outflow respectively. The radial artery was chosen due to a near one-to-one match, and because the hand was supplied by the ulnar artery on arteriogram. Three branches of the sensory radial nerve were preserved as well as the extensor pollicis longus and flexor pollicis longus muscle-tendon units. 


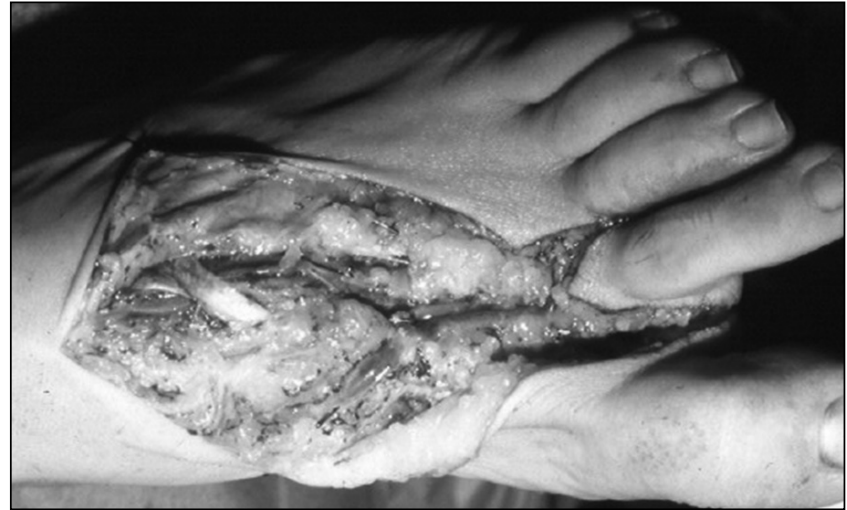

Figure 2) Foot dissection

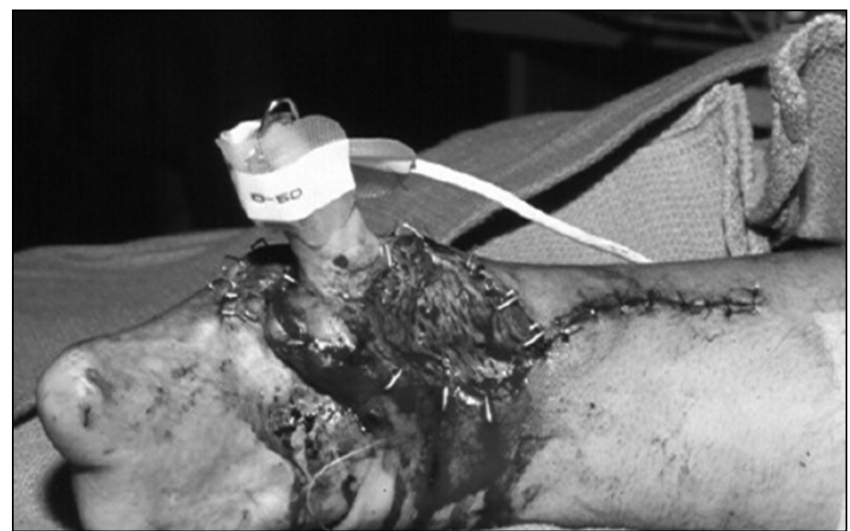

Figure 3) Oxygenation monitor

\section{Foot dissection}

A pie-shaped incision was used to expose and isolate superficial veins associated with the dorsal saphenous vein and the dorsalis pedis artery as it became the first dorsal metatarsal artery (Figure 2). The deep peroneal and two plantar digital nerves were preserved. The extensor and flexor tendons to the second toe were found, dissected and cut. The joint capsule of the toe was entered and released circumferentially.

The toe was fixed into a distal radius burr hole in a position of opposition with C-wires. The extensor and flexor tendons to the toe were approximated to the corresponding extensor pollicis longus and flexor pollicis longus. The dorsal and volar sensory nerves and the digital nerves were coapted under the microscope with their corresponding radial sensory and digital nerves. A 9.0 microsuture anastomosis of the dorsal saphenous vein into the second toe to the cephalic vein was accomplished. An end-to-end anastomosis between the radial artery and the first dorsal metatarsal branch of the dorsalis pedis artery was performed with 10.0 sutures. After flow was assured, the area was closed using local skin flaps and a split-thickness skin graft from the volar forearm. A volar splint was applied. The foot was closed over a Penrose drain. A pediatric pulse oximeter was sewn to the toe pulp with chromic catgut to follow inflow (Figure 3). This seemed a unique, simple and accurate oxygenation monitor.

\section{RESULTS}

The patient continues to have useful function of his reconstructed helper hand. He has protective sensation, two-point discrimination of $6 \mathrm{~mm}$ to $7 \mathrm{~mm}$, and a lateral pinch strength

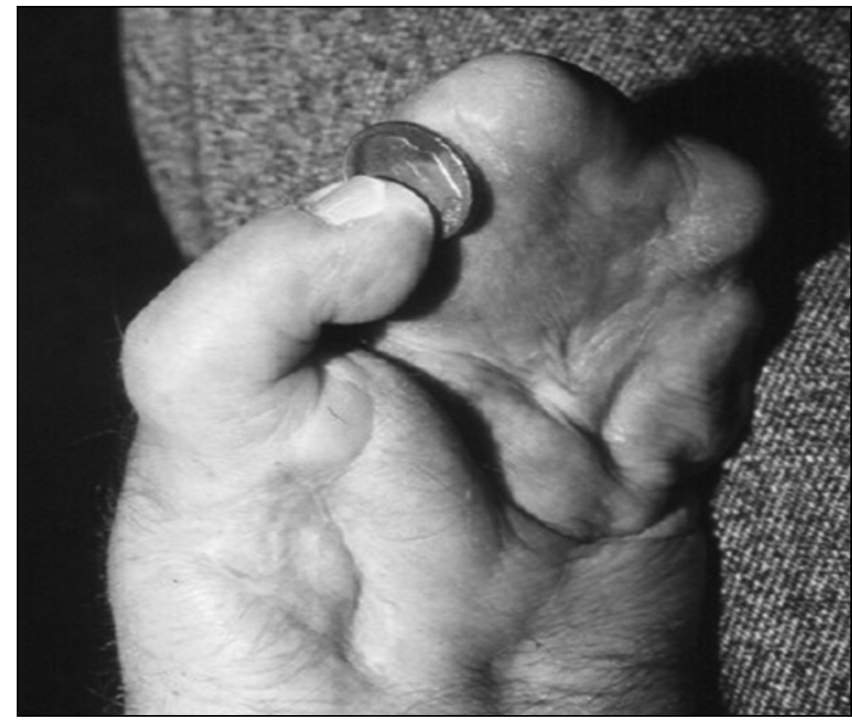

Figure 4) Fifteen-year follow-up: Fine pinch

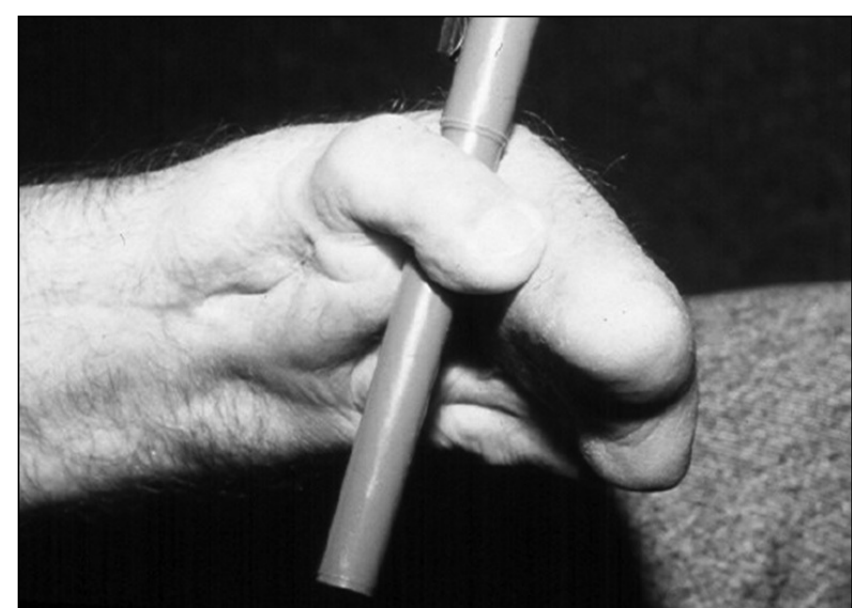

Figure 5) Fifteen-year follow-up: Grasp

of $7 \mathrm{lb}$. No foot disability or gait disturbances have occurred. He returned to work as a janitor in October 1994 and continues to be pleased with his result. Multiple daily traumas at work and at home have not significantly injured the transferred toe.

\section{DISCUSSION}

Free transfer of a great toe to replace an amputated thumb was first performed by Cobbett in 1969 (5). Transfer of a second toe for digital reconstruction was done by O'Brien in 1977 (6) and O'Brien et al in 1978 (7). Since these early single digit reconstructions, a myriad of variations have been used to restore function in increasingly complex injuries $(8,9)$. Our patient posed a problem in that his injury involved near total amputation of all digits and most of the hand. Our placement of the second toe to the radius in a nonanatomic fashion served as a stable foundation for creation of pinch function in a helper hand. The present case shows that a helper hand can provide a long-term, sensate and useful functional result in the setting of an otherwise devastating injury. This transfer has returned the patient to his original job and has stood a 15-year extraanatomic test of time (Figures 4 and 5). 


\section{REFERENCES}

1. Furnas DW, Achauer BM. Microsurgical transfer of the great toe to the radius to provide prehension after partial avulsion of the hand. J Hand Surg [Am] 1983;8:453-60.

2. Rui Y, Shou K, Zhang Q, Xu Y, Sun Z, Xu L. Combined free-tissue transfer for primary reconstruction of radial part of the hand. Microsurgery 2004;24:59-62.

3. Beasley RW, de Bese GM. Upper limb amputations and prostheses. Othop Clin North Am 1986;17:395-405.

4. Wright TW, Hagen AD, Wood MB. Prosthetic usage in major upper extremity amputations. J Hand Surg [Am] 1995;20:619-22.

5. Cobbett JR. Free digital transfer. Report of a case of transfer of a great toe to replace an amputated thumb. J Bone Joint Surg $\mathrm{Br}$ 1969;51:677-9
6. O’Brien B. One stage toe-to-hand surgery. Microvascular Reconstructive Surgery. London, Churchhill Livingstone, 1977:183-204.

7. O'Brien B, MacLeod AM, Sykes PJ, Browning FS, Threlfall GN. Microvascular second toe transfer for digital reconstruction. J Hand Surg [Am] 1978;3:123-33.

8. Tsai T, Jupiter JB, Wolff TW, Atasoy E. Reconstruction of severe transmetacarpal mutilating hand injuries by combined second and third toe transfer. J Hand Surg [Am] 1981;6:319-28.

9. Tan BK, Wei FC, Lutz BS, Lin CH. Strategies in multiple toe transplantation for bilateral type II metacarpal hand reconstruction. Hand Clin 1999;15:607-12. 